\title{
The Decision Support System Determines The Effectiveness Of The Pelita Nusantara STMIK Promotion Media With The Profile Matching Method
}

\author{
Ramli S. Siburian ${ }^{1}$, Agustina Simangunsong ${ }^{2}$ \\ ${ }^{1,2}$ Informatics Engineering, STMIK Pelita Nusantara, Sumatera Utara, Indonesia
}

\begin{tabular}{|c|c|}
\hline ARTICLE INFO & ABSTRACT \\
\hline Article history: & \multirow{4}{*}{$\begin{array}{l}\text { In carrying out promotional activities, the level of effectiveness of a } \\
\text { promotional media used by the promotion team greatly influences } \\
\text { the results to be achieved. Therefore, it is necessary to pay attention } \\
\text { to which promotional media is more appropriate to use when } \\
\text { conducting promotions. In decision making, the researcher uses the } \\
\text { Profile Matching method. The Profile Matching method is used as a } \\
\text { mechanism in decision making by assuming that there is an ideal } \\
\text { level of predictor variables that must be met by the subject under } \\
\text { study, not a minimum level that must be met or passed. In the Profile } \\
\text { Matching process, a comparison process will be carried out between } \\
\text { individual competencies into standard competencies, in this case the } \\
\text { ideal Raskin profile, so that differences in competence can be } \\
\text { known. From the decision-making process carried out will obtain the } \\
\text { results of the most effective promotional media used in carrying out } \\
\text { promotional activities. }\end{array}$} \\
\hline $\begin{array}{r}\text { Received Nov 9, } 2021 \\
\text { Revised Nov 20, } 2021 \\
\text { Accepted Des 08, } 2021\end{array}$ & \\
\hline Keywords: & \\
\hline $\begin{array}{r}\text { Promotion Media; } \\
\text { Profile Matching; } \\
\text { Promotion. }\end{array}$ & \\
\hline
\end{tabular}

This is an open access article under the CC BY-NC license.

\section{Corresponding Author:}

Agustina Simangunsong,

Informatics Engineering,

STMIK Pelita Nusantara, Sumatera Utara, Indonesia

Jl. Iskandar Muda No.1 Medan, Sumatera Utara, Indonesia

Email: agustinasimangunsong93@gmail.com

\section{INTRODUCTION}

The development of science is an important aspect of globalization, especially in the field of education (Dale, 1999) (Dale, 2000). With the development of globalization, of course, there are impacts that we face, in anticipating the impact of globalization that occurs in the world of education, decision-making has an impact on the results to be obtained (Weiss, 2005). Decisionmaking that is carried out quickly and accurately can have a major impact on success in global competition in the future (Carneiro, 2000).

STMIK Pelita Nusantara, one of the private universities (PTS) located in the city of Medan, North Sumatra Province. STMIK Pelita Nusantara was established on September 5, 2003. Every year STMIK Pelita Nusantara carries out promotional activities for new student admissions, in conducting promotions it is necessary to pay attention to which alternative is more effective to attract the attention of prospective new students.

Profile Matching is a suitable method to use in decision making, because profile matching uses a process of comparing the value of the initial competency standard aspect with the input competency which will be ranked based on the highest value (Simbolon \& Sinaga, 2021) (Sugiarti et al., 2018). 


\section{METHOD}

Promotion is a communication activity carried out by a person or a company with the wider community, where the aim is to introduce something (goods, services, brands, companies) to the community and at the same time influence the wider community to buy and use the products or services offered (Rian \& Fuadytama, 2019) (Sinaga \& Sinaga, 2019).

The decision support system is an interactive system that supports decisions in the decisionmaking process through alternatives obtained from the results of data processing, information, and model design (Wicaksono et al., 2020) (Nofriansyah \& Defit, 2017).

Profile matching is a decision-making mechanism by assuming that there is an ideal level of predictor variables that must be met by the subject under study, not a minimum level that must be met or passed (Ernawati et al., 2017) (Purba, 2018). The following are the stages of using profile matching (Apriana, 2019) (Sutabri, 2016):

1) Determine alternatives and aspects used

2) Calculation of GAP value

\section{Gap $=$ Minimal Profile - Test data profile}

3) After obtaining the Gap value, then weighting is given to each GAP value (GAP mapping).

4) Calculation and grouping of Core Factor and Secondary Factor

a. Core Factor (Main Factor) is a criterion (competence) that is most important or prominent or most needed by an assessment that is expected to obtain optimal results

$$
N C F=\frac{\sum N C}{\sum I C}
$$

b. Secondary Factors (supporting factors), which are items other than those in the core factor. Or in other words, it is a supporting factor that is less needed by an assessment.

$$
N C F=\frac{\sum N S}{\sum I S}
$$

c. Total Value Calculation

Total value is obtained from the percentage of core factor and secondary factor which is estimated to affect the results of each profile.

d. Calculation of Ranking

$$
\mathrm{N}=(\mathrm{x}) \% \mathrm{NCF}+(\mathrm{x}) \% \mathrm{NSF}
$$

The final result of the profile matching process is ranking. Determination of ranking refers to the results of certain calculations.

$$
\text { Rank }=(x) \% \text { NMA + (X) \% NSA }
$$

Unified Modeling Language is one of the language standards that is widely used in the industry for defining requirements, making analysis \& design, and describing architecture in objectoriented programming. Here are some UML functions:

1) To describe system boundaries and system functions in general.

2) To describe activities or business processes carried out in general.

3) To describe the representation of the static structure of a system in the form of class diagrams.

4) To create a behavior model "which describes the behavior or nature of a system" with a state transition diagram.

5) To state the physical implementation architecture using components and development diagrams.

\section{RESULTS AND DISCUSSIONS}

After data collection is carried out, the method is applied to obtain results. The following are the stages of analysis: 
a. Determining the Alternatives and Aspects to be used.

Table 1.

Aspect

\begin{tabular}{|c|c|c|c|c|}
\hline Num & Aspect & $\begin{array}{c}\text { Aspect Weight } \\
\text { Value }\end{array}$ & Sub Aspect & $\begin{array}{l}\text { Sub Aspect } \\
\text { Profile }\end{array}$ \\
\hline \multirow[t]{2}{*}{1} & \multirow{2}{*}{ Reach Aspect } & \multirow[t]{2}{*}{$30 \%$} & In the city (AJ1) & 5 \\
\hline & & & $\begin{array}{l}\text { Out of town (AJ2) } \\
\text { Hiah school/vocational }\end{array}$ & 4 \\
\hline \multirow{2}{*}{2} & \multirow{2}{*}{ Target Aspect } & \multirow{2}{*}{$35 \%$} & school students (AS1) & 5 \\
\hline & & & $\begin{array}{l}\text { Public (AS2) } \\
\text { Employee (AS3) } \\
\text { Inexpensive (AB1) }\end{array}$ & $\begin{array}{l}4 \\
4 \\
4\end{array}$ \\
\hline \multirow[t]{2}{*}{3} & \multirow[t]{2}{*}{ Target Aspect } & \multirow[t]{2}{*}{$20 \%$} & Currently (AB2) & 3 \\
\hline & & & $\begin{array}{l}\text { Expensive (AB3) } \\
\text { Very satisfy }(A H 1)\end{array}$ & $\begin{array}{l}3 \\
5\end{array}$ \\
\hline \multirow[t]{2}{*}{4} & \multirow[t]{2}{*}{ Result Aspect } & \multirow[t]{2}{*}{$15 \%$} & Satisfying (AH2) & 3 \\
\hline & & & Less satisfactory ( $\mathrm{AH} 3$ ) & 2 \\
\hline
\end{tabular}

Table 2.

Alternative

\begin{tabular}{ccc}
\hline Num & Alternate Code & Alternative name \\
\hline 1 & A1 & Brochure \\
2 & A2 & Banner \\
3 & A3 & Billboard \\
4 & A4 & Socialization \\
5 & A5 & Social media \\
6 & A6 & Website \\
7 & A7 & Alumni \\
8 & A8 & Student \\
\hline
\end{tabular}

b. Normalize data based on data obtained during data research.

Table 3.

Data Normalization

\begin{tabular}{|c|c|c|c|c|c|c|c|c|c|c|c|c|}
\hline \multirow[t]{2}{*}{ Num } & \multirow[t]{2}{*}{ Alternative } & \multicolumn{2}{|c|}{$\begin{array}{l}\text { Reach } \\
\text { Aspect }\end{array}$} & \multicolumn{3}{|c|}{ Target Aspect } & \multicolumn{3}{|c|}{ Cost Aspect } & \multicolumn{3}{|c|}{ Result Aspect } \\
\hline & & AJ1 & AJ2 & AS1 & AS2 & AS3 & AB1 & $\mathrm{AB2}$ & AB3 & $\overline{\mathrm{AH} 1}$ & $\mathrm{AH} 2$ & $\mathrm{AH} 3$ \\
\hline 1 & A1 & 4 & 2 & 4 & 2 & 2 & 5 & 3 & 2 & 1 & 3 & 4 \\
\hline 2 & A2 & 4 & 3 & 3 & 3 & 3 & 4 & 3 & 2 & 1 & 3 & 4 \\
\hline 3 & A3 & 4 & 2 & 3 & 3 & 3 & 4 & 3 & 2 & 1 & 3 & 4 \\
\hline 4 & A4 & 4 & 4 & 5 & 2 & 2 & 3 & 3 & 4 & 5 & 3 & 2 \\
\hline 5 & A5 & 5 & 5 & 4 & 4 & 4 & 5 & 4 & 3 & 5 & 2 & 1 \\
\hline 6 & A6 & 5 & 5 & 3 & 4 & 4 & 5 & 4 & 2 & 3 & 3 & 4 \\
\hline 7 & A7 & 5 & 5 & 4 & 4 & 4 & 5 & 3 & 1 & 3 & 3 & 1 \\
\hline 8 & A8 & 5 & 5 & 5 & 4 & 4 & 3 & 4 & 4 & 5 & 5 & 2 \\
\hline
\end{tabular}

c. Next, the GAP calculation will be carried out, the GAP calculation is obtained by subtracting the sub-aspect input value from the sub-aspect profile that has been determined by the head of the STMIK Pelita Nusantara Promotion team.

$$
\text { GAP = alternative assessment }- \text { sub aspect profile }
$$

Table 4.

GAP Aspect Value Reach

$\begin{array}{lll}\text { Alternative } & \text { AJ1 } & \text { AJ2 }\end{array}$




\begin{tabular}{ccc}
\hline Alternative & AJ1 & AJ2 \\
\hline A1 & 4 & 2 \\
A2 & 4 & 3 \\
A3 & 4 & 2 \\
A4 & 4 & 4 \\
A5 & 5 & 5 \\
A6 & 5 & 5 \\
A7 & 5 & 5 \\
A8 & 5 & 5 \\
\hline GAP value & 5 & 4 \\
A1 & -1 & -2 \\
A2 & -1 & -1 \\
A3 & -1 & -2 \\
A4 & -1 & 0 \\
A5 & 0 & 1 \\
A6 & 0 & 1 \\
A7 & 0 & 1 \\
A8 & 0 & 1 \\
\hline
\end{tabular}
aspect.

Furthermore, the same process is carried out on the target aspect, cost aspect and outcome

d. After obtaining the GAP value, GAP mapping is then carried out which is sourced from the GAP analysis.

Table 5.

GAP Mapping

\begin{tabular}{cccccccccccc}
\hline Alternative & \multicolumn{3}{c}{ Reach Aspect } & \multicolumn{3}{c}{ Target Aspect } & \multicolumn{3}{c}{ Cost Aspect } & \multicolumn{3}{c}{ Result Aspect } \\
\cline { 2 - 11 } & AJ1 & AJ2 & AS1 & AS2 & AS3 & AB1 & AB2 & AB3 & AH1 & AH2 & AH3 \\
A1 & 4 & 3 & 4 & 3 & 3 & 4,5 & 5 & 4 & 1 & 5 & 3,5 \\
A2 & 4 & 4 & 3 & 4 & 4 & 5 & 5 & 4 & 1 & 5 & 3,5 \\
A3 & 4 & 3 & 3 & 4 & 4 & 5 & 5 & 4 & 1 & 5 & 3,5 \\
A4 & 4 & 5 & 5 & 3 & 3 & 4 & 5 & 4,5 & 5 & 5 & 5 \\
A5 & 5 & 4,5 & 4 & 5 & 5 & 4,5 & 4,5 & 5 & 5 & 4 & 4 \\
A6 & 5 & 4,5 & 3 & 5 & 5 & 4,5 & 4,5 & 4 & 3 & 5 & 3,5 \\
A7 & 5 & 4,5 & 4 & 5 & 5 & 4,5 & 5 & 3 & 3 & 5 & 4 \\
A8 & 5 & 5 & 5 & 5 & 5 & 4 & 4,5 & 4,5 & 5 & 3,5 & 5 \\
\hline
\end{tabular}

e. The next step is to calculate the value of the core factor and secondary factor. In the research conducted, based on the data determined by the head of the STMIK Pelita Nusantara promotion team, the Reach and Target Aspects were the core factors (CF) with a value of $70 \%$, while the Cost Aspects and Outcome Aspects were the secondary factors (SF) with a value of $30 \%$.

Table 6.

Calculation of the value of core factor and secondary factor

\begin{tabular}{ccccc}
\hline Alternative & Reach Aspect & Target Aspect & Cost Aspect & Result Aspect \\
\hline A1 & 3,50 & 3,33 & 4,50 & 3,17 \\
A2 & 4,00 & 3,67 & 4,67 & 3,17 \\
A3 & 3,50 & 3,67 & 4,67 & 3,17 \\
A4 & 4,50 & 3,67 & 4,50 & 5,00 \\
A5 & 4,75 & 4,67 & 4,67 & 4,33 \\
A6 & 4,75 & 4,33 & 4,33 & 3,83 \\
A7 & 4,75 & 4,67 & 4,17 & 4,00 \\
A8 & 4,75 & 5,00 & 4,33 & 4,50 \\
Information & Core factor & Core factor & Secondary & Secondary \\
& & & factor & factor \\
\hline
\end{tabular}


f. After the CF and SF values are determined, the next step is to calculate the total value. By multiplying the average number of CF/SF values by the CF/SF weights.

Table 7.

Total Value Calculation

\begin{tabular}{ccccc}
\hline Alternative & Reach Aspect & Target Aspect & Cost Aspect & Result Aspect \\
\hline A1 & 2,45 & 2,33 & 1,35 & 0,95 \\
A2 & 2,80 & 2,57 & 1,40 & 0,95 \\
A3 & 2,45 & 2,57 & 1,40 & 0,95 \\
A4 & 3,15 & 2,57 & 1,35 & 1,50 \\
A5 & 3,33 & 3,27 & 1,40 & 1,30 \\
A6 & 3,33 & 3,03 & 1,30 & 1,15 \\
A7 & 3,33 & 3,27 & 1,25 & 1,20 \\
A8 & 3,33 & 3,50 & 1,30 & 1,35 \\
\hline
\end{tabular}

g. The next step is to determine the ranking to perform the ranking by multiplying the value of each aspect weight by the total value of each aspect.

Table 8.

Rank Finding Calculation

\begin{tabular}{ccc}
\hline Alternative & Final score & Information \\
\hline A1 & 1,82 & 8 \\
A2 & 2,02 & 6 \\
A3 & 1,91 & 7 \\
A4 & 2,11 & 5 \\
A5 & 2,42 & 2 \\
A6 & 2,32 & 4 \\
A7 & 2,39 & 3 \\
A8 & 2,48 & 1 \\
\hline
\end{tabular}

\section{CONCLUSION}

Based on the research conducted, it can be concluded that in the decision support system research to determine the level of effectiveness of STMIK Pelita Nusantara Promotional Media with the ProfileMatching Method, several conclusions were obtained, namely: The application of the profile matching method to the decision support system to determine the level of effectiveness of the STMIK Pelita Nusanta promotional media is done by determining what are the alternative promotional media, aspects and sub-aspects of support in carrying out promotional activities, then comparing alternative profiles to supporting aspects so that differences in competence can be found (called GAP). Then do a mapping of the GAP values obtained to produce the core factor and secondary factor values so as to produce the final value. In this study, the student alternative (A8) is the most effective alternative used according to the calculations carried out with a final score of 2.48. In designing a decision support system, determining the level of effectiveness of STMIK Pelita Nusantara promotional media is done by designing use case diagrams, activity diagrams, and class diagrams. Then it is applied/built using the PHP programming language and MySQLI database. Which can then be used by the STMIK Pelita Nusantara promotion team to determine which promotional media are more effective in carrying out promotional activities.

\section{References}

Apriana, V. (2019). Penerapan Profile Matching Untuk Menentukan Pemberian Beasiswa Pada Siswa Sekolah Menengah Atas. Jurnal Mantik Penusa, 3(1, Juni).

Carneiro, A. (2000). How does knowledge management influence innovation and competitiveness? Journal of Knowledge Management.

Dale, R. (1999). Specifying globalization effects on national policy: a focus on the mechanisms. Journal of Education Policy, 14(1), 1-17.

Dale, R. (2000). Globalization and education: demonstrating a" common world educational culture" or locating a" globally structured educational agenda"? Educational Theory, 50(4), 427. 
Ernawati, E., Hidayah, N. A., \& Fetrina, E. (2017). Rancang Bangun Sistem Pendukung Keputusan Kenaikan Jabatan Pegawai Dengan Metode Profile Matching (Studi Kasus: Kementerian Agama Kantor Wilayah DKI Jakarta). Studia Informatika: Jurnal Sistem Informasi, 10(2).

Nofriansyah, D., \& Defit, S. (2017). Multi Criteria Decision Making (MCDM) pada Sistem Pendukung Keputusan. Deepublish.

Purba, D. H. P. (2018). Sistem informasi akuntansi penggajian dan pengupahan: Studi kasus pada sebuah rumah sakit. Jurnal Manajemen, 4(1), 15-22.

Rian, H., \& Fuadytama, A. (2019). Perancangan Sistem Informasi Pelayanan Jasa Laundry Pada Mamah Laundry And Cleaners Serang. Jurnal Teknologi Informatika Dan Komputer, 5(2), 64-69.

Simbolon, D. S., \& Sinaga, B. (2021). Sistem Pendukung Keputusan Penentuan Kesesuaian Lahan Tanaman Cengkeh Dengan Metode Profile Matching. Jurnal Nasional Komputasi Dan Teknologi Informasi (JNKTI), 4(5), 370-379.

Sinaga, J., \& Sinaga, B. (2019). SISTEM PENDUKUNG KEPUTUSAN PENENTUAN STRATEGI PROMOSI STMIK PELITA NUSANTARA MENGGUNAKAN METODE AHP. JURNAL SAINS DAN TEKNOLOGI, 1(1), 58-62.

Sugiarti, S., Nahulae, D. K., Syafrizal, S., Panggabean, T. E., \& Sianturi, M. (2018). Sistem Pendukung Keputusan Penentuan Kebijakan Strategi Promosi Kampus Dengan Metode Weighted Aggregated Sum Product Assesment (WASPAS). JURIKOM (Jurnal Riset Komputer), 5(2), 103-108.

Sutabri, T. (2016). Sistem informasi manajemen.

Weiss, L. (2005). The state-augmenting effects of globalisation. New Political Economy, 10(3), 345-353.

Wicaksono, M. R., Sakaria, S., \& Oktavia, C. A. (2020). Sistem Pendukung Keputusan Untuk Mempermudah Kinerja Dalam Proses Penerimaan Beasiswa Menggunakan Metode SAW (Simple Additive Weighting) Berbasis Web (Studi Kasus: SMAS Empat Lima 1 Babat). J-INTECH, 8(01), 30-38. 